\title{
Albinisme er ingen sykdom
}

\author{
Vi trenger ingen kur for albinisme, \\ men dropp solkremen og send \\ albinismebarna til Syden!
}

Da jeg var liten, var det mye diskusjon om jeg skulle få være med til Syden eller ikke - solen er jo så farlig, ble det sagt. Jeg ble derfor alltid stasjonert hos besteforeldrene mine hjemme i Norge om sommeren mens resten av familien dro av sted med charterfly. Det føltes urettferdig - for alle dro jo til Syden. Jeg lurte ofte på hvordan det egentlig var der nede, på skolen pratet alle om hvor kult det var i Syden. Allikevel var det et uendelig mas om solkrem og kortbukser - ta nå på deg kortbuksene, men pass på så du ikke blir brent. Jeg ville heller ha på meg langbukse og langermet genser enn solkrem fordi jeg var flau over den rosableke huden min. Dessuten luktet det sykehus av den klissete, ekle solkremen.

Som voksen bestemte jeg meg for å reise til et virkelig tropisk land - uten solkrem. Hva fant jeg? Lokalbefolkningen unngår solen som pesten! Det virker som at jo varmere landet er, desto mer legitimt er det å holde seg borte fra solen. Perfekt - spesielt i når vi kommer fra et land hvor alle desperat kaster klærne så fort solen stikker frem.

Faren for hudkreft er én ting, mennesker er noe annet. Jeg møter hovedsakelig to typer mennesker - de som påpeker at jeg er albino, og de som ikke sier noe. Hva er egentlig en albino? Er det et menneske eller et skjellsord? Det finnes mange fordommer og stygge påstander om albinoer.
Jeg insisterer derfor alltid på bruken av begrepet «albinisme» som en egenskap ved et menneske, og hevder at «albinoer» som overnaturlige, skumle vesener kun finnes i en fantasiverden. Men i en tidsalder fylt med science fiction er det litt kulere å referere til seg til seg selv som mutant enn å lene seg på en tørr og mer korrekt forklaring basert på gener og arv.

Jeg var ikke gammel da jeg ble eksponert for den uønskede oppmerksomheten og ble meg bevisst at jeg ser helt annerledes ut. Som liten var mitt største ønske å være som alle andre, helst en som var usynlig i mengden. Med konstant uønsket oppmerksomhet gir også god trening i å håndtere å bli lagt merke til. I den grad albinisme er en funksjonsnedsettelse, er vil jeg påstå at det hovedsakelig er en sosial funksjonsnedsettelse som skyldes dem man møter, ikke en egentlig vesentlig fysisk funksjonsnedsettelse.

Jo, litt tykke brilleglass har jeg. Jeg går rett i lysstolper og glassvinduer et par ganger i året, jeg kan antakeligvis aldri kjøre bil, og skjelveøynene (nystagmus) forvirrer nok noen av dem jeg prater med. Men dette er ikke egentlig noe problem. Uavhengig av visus ser jeg det jeg trenger å se, jeg kan lese det meste og gjøre jobben min - og jeg kan verdsette synet av vakre kvinner, skjønn natur og interessante gjenstander.

Finnes det en kur for albinisme? Hva med å operere bort nystagmusen? Jeg traff en gang et foreldrepar med en liten jente med albinisme som ble spurt om hun ville sagt ja dersom det fantes en kur for albinisme. Hun svarte selvsikkert: «Nei, da ville jo ikke jeg være meg!» Kloke ord fra et lite barn.
Heldigvis var jeg første generasjon albinismebarn som slapp å gå på spesialskole, men spesialutstyr slapp jeg ikke unna. Jeg fikk en ekstremt stor pult, med en arbeidsflate som kunne vippes, og en gedigen arbeidslampe. Pulten sto på første rad slik at jeg følte at alle så på meg. Egentlig ville jeg ha en helt vanlig pult. Pulten fulgte meg igjennom hele grunnskolen. Da jeg skulle begynne på videregående, trodde jeg at jeg endelig var fri, men nei, pulten ble med! Ingen skal beskylde hjelpemiddelsentralen for ineffektivitet. For stakkarene som går på skolen nå, er det blitt enda verre. Pultene er blitt enda større, og med dokumentkameratårn ser de ut som noe fra verdensrommet.

Over tid har det intense ønsket om å være som alle andre endret seg til en erkjennelse av at det ligger unike muligheter $\mathrm{i}$ annerledesheten. Mitt levebrød er å være forsker og leder. Forskere strever med å få oppmerksomhet og å bli husket. Ledere må håndtere konstant kritisk oppmerksomhet. Personer med albinisme lærer å håndtere oppmerksomhet. Vi kan utvikle strategier for å utnytte den visuelle annerledesheten på en verdig og positiv måte.

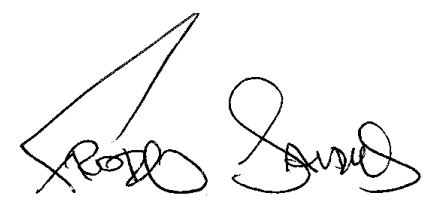

